\title{
Efficacy of fresh and air-dried biosolids as amendments for remediation of acidic and metal-polluted soils: A short-term laboratory assay
}

\author{
R. Ginocchio ${ }^{1,2^{*}}$,V. Cárcamo ${ }^{3}$, E. Bustamante 2 , E. Trangolao ${ }^{2}$, L. M. de la Fuente ${ }^{2}$, A. Neaman ${ }^{4}$ \\ ${ }^{1}$ Departamento de Ecosistemas y Medio Ambiente, Facultad de Agronomía e Ingeniería Forestal, Pontificia \\ Universidad Católica de Chile, Santiago, Chile. ${ }^{2}$ Centro de Investigación Minera y Metalúrgica, Santiago, Chile. \\ ${ }^{3}$ Facultad de Ciencias Agronómicas, Universidad de Chile, Santiago, Chile. ${ }^{4}$ Facultad de Agronomía, Pontificia \\ Universidad Católica de Valparaíso, Valparaíso, Chile. *Corresponding author: rosanna.ginocchio@uc.cl
}

\begin{abstract}
Biosolids have been used as amendments on mine degraded soils for in situ immobilization of metals, neutralization, and improvement of nutritional, microbiological, and physical characteristics to reestablish a self-sustaining plant community. Fresh and air-dried biosolids have been used but dried ones are preferred as they are cheaper to transport, contain less pathogens and are much easier to handle. The same efficacy has been assumed for both biosolids. The study evaluated the effects of fresh and air-dried biosolids on physical, chemical and microbiological characteristics of an acidic and metal/As-rich soil of the Puchuncaví valley, central Chile, and on plant yield under laboratory conditions. Two doses of each biosolids were used (50 and 100 ton ha ${ }^{-1}$, dry weight). Fresh and air-dried biosolids similarly increased organic matter, total nitrogen $(\mathrm{N})$ and available $\mathrm{N}$ and phosphorous contents of study soil. However, air-dried biosolids exhibited lower field capacity and higher wilting point, salinity, higher levels of dissolved organic carbon, concentrations of total dissolved copper and zinc, and lower activity of free $\mathrm{Cu}^{2+}$ ions in pore water. Basal respiration was significantly increased by incorporation of biosolids into soils, irrespective of being fresh or air-dried ones. In terms of aerial plant productivity, fresh biosolids and low doses of air-dried biosolids significantly increased this characteristic. However, high doses of air-dried biosolids limited aerial biomass and root cover, probably due to soil salinity and water stress. Therefore, fresh biosolids are suggested for remediation of this mine degraded soils.
\end{abstract}

Keywords: Plant yield, microbial activity, sewage sludge, mine site remediation, organic soil amendments 


\section{Introduction}

Soils of the Puchuncaví valley, a coastal area in central Chile, are heavily polluted due to operation of a Cu-smelter under no environmental regulations from 1964 to 1992 (Environmental Resources Management, 1993). Elevated atmospheric emissions of sulphur dioxide (mean of 399 ton d $^{-1}$; Environmental Resources Management, 1993) resulted in strong acid rain deposition with acute damage to local vegetation and soil acidification to a $\mathrm{pH}$ of 3.5 - 4.7 (Ginocchio, 2000). Furthermore, atmospheric emission and fallout of trace element-rich particulate matter (mean of 12 ton $\mathrm{d}^{-1}$; Environmental Resources Management, 1993) resulted on metal (i.e. $\mathrm{Cu}, \mathrm{Zn}, \mathrm{Pb}, \mathrm{Cd}$ ) and arsenic (As) enrichment of soils and strong reduction on plant richness and abundance (Ginocchio, 2000; González et al., 2008; Neaman et al., 2009). A consequent impoverishment of soils occurred after the years due to wind and rain erosion, particularly in terms of both organic matter and macronutrient contents (Ginocchio, 2000). Such land degradation has been also a major concern in other mining countries (i.e. Canada).

Atmospheric emissions from the $\mathrm{Cu}$-smelter were effectively controlled by 1999 through technological improvements to comply with new environmental regulations established in the country. However, largescale and cost-effective remediation actions are needed to reverse the strong environmental impacts occurred. Simultaneous in situ immobilization of metals/As in topsoils, soil neutralization, and improvement of nutritional, microbiological, and physical characteristics of degraded soils are required for the reestablishment of a self-sustaining plant community at degraded areas of the Puchuncaví valley. A soil amendment widely used in the United States to cope with all these soil limitations is municipal biosolids (U.S. EPA, 2007). Biosolids are both macronutrientand organic matter(OM)-rich residues (Brown et al., 2003; 2009), which improve soil fertility (particularly $\mathrm{N}$ and $\mathrm{P}$ content) and some physical characteristics of soils, such as water holding capacityand texture (U.S. EPA, 2007; Lu et al., 2012). Furthermore, OM decreases metal/As bioavailability in polluted soils, and thus phytotoxicity, as it is an effective sorbent for both metal cations and anions (U.S. EPA, 2007; Bes \&Mench, 2008; Kumpiene et al., 2008).

Biosolids are digested sewage sludges or the primary organic solid residues yielded by municipal wastewater treatment plants (Haering et al., 2000). They are normally disposed in land fields, incinerated and/or reused as soil amendments, particularly when they have non-detectable (class A) or very low (class B) pathogen levels (Wang et al., 2008). As they are produced in large volumes and obtained free of charge, biosolids are readily available soil organic amendments. Therefore, a growing interest in using them to remediate metal/metalloid-degraded soils has occurred in the last decades, including polluted soils of the Puchuncaví valley (Cárcamo et al., 2012). For example, biosolids have been effectively used as organic amendments on strip mines, coal refuse piles, and other mine disturbed soils and solid mine wastes (Haering et al., 2000; Brown et al., 2003; Santibáñez et al., 2008; Brown et al., 2009).

A common feature of fresh biosolids is their high moisture content (> 60-70\%; Wang et al., 2008). This characteristic normally increases transportation costs from municipal plants to land application sites (e.g. croplands, degraded soils, mine land restoration). A number of methods have been developed for removing water from fresh biosolids to values lower than 30\% moisture content, including air-drying and thermaldrying (Lu et al., 2012). Furthermore, dry biosolids are much easier to handle compared to fresh one sand contain less pathogen ( $\mathrm{Lu}$ et al., 2012). Irrespective of the costs, management alternatives and pathogen content issues involved, it is normally assumed that fresh and dry biosolids have the same positive effects on physical, chemical and microbiological characteristics of amended soils and on plant yields. There is, however, evidence that drying processes result in chemical changes of biosolids, particularly 
in the amounts and forms of nutrients. For example, transformation of phosphorous forms from organic to inorganic and increases in easily-mineralizable organic nitrogen (Lu et al., 2012).These changes may be very relevant when using biosolids as organic soil amendments, but they have not been well studied yet.

In the case of polluted soils of the Puchuncaví valley, research is needed to evaluate the efficacy of fresh and dry biosolids on soil remediation with particular emphasis on their efficacy for in situ immobilization of metals/metalloids and improvement of key physical, nutritional and microbial properties of degraded soils, as transportation costs and application alternatives strongly differ among both biosolids. Therefore, a laboratory evaluation on the efficacy of Class B biosolids, either fresh or air-dried, as potential organic amendments for remediation of the acidic and metal/ As-rich soils of the Puchuncaví valley was carried out in the present study.

\section{Materials and Methods}

\subsection{Experimental soils}

A $80-\mathrm{kg}$ batch of polluted topsoil $(0-30 \mathrm{~cm}$ depth) of the Puchuncaví valley, Valparaíso Region of central Chile, was collected at Los Maitenes $\left(34^{\circ} 45^{\prime} \mathrm{S}, 71^{\circ}\right.$ $29^{\prime} \mathrm{W}$ ), a site located $2 \mathrm{~km}$ to the southwest of the $\mathrm{Cu}$ smelter. The same amount of topsoil was collected from a reference site $\left(32^{\circ} 47^{\prime} \mathrm{S}, 71^{\circ} 31^{\prime} \mathrm{W}\right)$ located $5 \mathrm{~km}$ to the south of the smelter facility; this soil was used as a positive control $(\mathrm{C}+)$. Composite samples of topsoils were collected at each site with a stainless steel shovel and transported to the laboratory in plastic containers. Soils were homogenized, steam-sterilized $\left(70{ }^{\circ} \mathrm{C}\right.$ ) to eliminate the seed bank, dried at $30^{\circ} \mathrm{C}$, and sieved to pass a $<2 \mathrm{~mm}$ nylon mesh. Elimination of viable seeds from study soils was required to avoid any type of interference in the plant cultivation assay described below. A summary of selected properties of study soils is given in Table 1. Polluted and reference reference site soils were alike with the exception of $\mathrm{pH}$ (one unit lower at Los Maitenes), and total $\mathrm{Cu}, \mathrm{Zn}, \mathrm{Cd}$, $\mathrm{Pb}$, and As contents (from 1.4 to 4.5 times higher at Los Maitenes; Table 1).

Table 1. General physicochemical characteristics of polluted (Los Maitenes site) and reference soils collected at the Puchuncaví valley, central Chile.

\begin{tabular}{|c|c|c|}
\hline Characteristic & Polluted soil & Reference soil \\
\hline Sand (\%) & 78 & 83 \\
\hline Clay (\%) & 3 & 3 \\
\hline Silt (\%) & 19 & 14 \\
\hline Bulk density $\left(\mathrm{g} \mathrm{cm}^{-3}\right)$ & 1.4 & 1.4 \\
\hline $\mathrm{pH}$ (water) & 5.58 & 6.30 \\
\hline $\mathrm{EC}\left(\mathrm{mS} \mathrm{cm}^{-1}\right)$ & 0.14 & 0.17 \\
\hline $\mathrm{CEC}\left(\mathrm{cmol}_{+} \mathrm{kg}^{-1}\right)$ & 9.07 & 8.55 \\
\hline Organic matter (\%) & 2.10 & 1.25 \\
\hline Total N (\%) & 0.09 & 0.06 \\
\hline Available $\mathrm{N}\left(\mathrm{mg} \mathrm{kg}^{-1}\right)$ & 29.4 & 15.3 \\
\hline Available $\mathrm{P}\left(\mathrm{mg} \mathrm{kg}^{-1}\right)$ & 42.5 & 33.1 \\
\hline Available $\mathrm{K}\left(\mathrm{mg} \mathrm{kg}^{-1}\right)$ & 216 & 267 \\
\hline Total $\mathrm{Cu}\left(\mathrm{mg} \mathrm{kg}^{-1}\right)$ & 685 & 209 \\
\hline Total Zn (mg kg-1) & 159 & 115 \\
\hline Total Cd (mg kg-1) & 0.9 & 0.2 \\
\hline Total Pb (mg kg $\left.{ }^{-1}\right)$ & 85 & 19 \\
\hline Total Fe (\%) & 5 & 5 \\
\hline Total As (mg kg $\left.{ }^{-1}\right)$ & 51 & 21 \\
\hline
\end{tabular}

EC, electrical conductivity; CEC, cation exchange capacity

\subsection{Selected Biosolids}

All biosolids used in the present study were Class B biosolids generated at El Trebal wastewater treatment plant of Aguas Andinas S.A., Metropolitan Region of central Chile. Two types of biosolids were used; the fresh ones came directly from the centrifuge at the end of the anaerobic stage of the wastewater treatment process (centrifuged biosolids; $\mathrm{Bc}$ ).

Biopolimers are used for precipitation of biosolids during centrifugation process; no alkaline materials are added into biosolids. The dried ones came from the solar drying beds of the wastewater treatment plant, after an air drying period of some months (dried biosolid; Bd). Dried biosolids have 2.5 times less water than fresh biosolids (Table 2). 
Table 2. General physicochemical characteristics of fresh and air-dried class B biosolids of El Trebal Plant, Aguas Andinas S.A., Metropolitan Region of Chile, used in the present study.

\begin{tabular}{|c|c|c|}
\hline \multirow[t]{2}{*}{ Characteristic } & \multicolumn{2}{|c|}{ Biosolids } \\
\hline & Fresh & Air-dried \\
\hline $\mathrm{pH}$ (water) & 7.54 & 6.77 \\
\hline $\mathrm{EC}\left(\mathrm{mS} \mathrm{cm}^{-1}\right)$ & 14.0 & 27.2 \\
\hline $\mathrm{OM}(\%)$ & 31.9 & 28.2 \\
\hline CEC $\left(\mathrm{cmol}_{+} \mathrm{kg}^{-1}\right)$ & 52.3 & 43.7 \\
\hline Total N (\%) & 3.0 & 4.4 \\
\hline Total P (P2O5) (\%) & 5.5 & 2.1 \\
\hline Total K (K2O) (\%) & 0.3 & 0.3 \\
\hline Sulfate $\left(\mathrm{mg} \mathrm{L}^{-1}\right)$ & 9,438 & 27,811 \\
\hline Total Cu (mg kg-1) & 866 & 825 \\
\hline Total Zn $\left(\mathrm{mg} \mathrm{kg}^{-1}\right)$ & 1,371 & 1,639 \\
\hline Total Fe (\%) & 2.1 & 1.4 \\
\hline Total Ca (\%) & 4.3 & 1.0 \\
\hline Total As $\left(\mathrm{mg} \mathrm{kg}^{-1}\right)$ & 17.9 & 18.4 \\
\hline Total solids (\%) & 70 & 77 \\
\hline Water content (\%) & 76 & 31 \\
\hline
\end{tabular}

General physicochemical characteristics of both fresh and dried biosolids are given in Table 2. They indicate that dried biosolids have higher values of electrical conductivity (EC) and sulfate content and lower contents of organic matter $(\mathrm{OM})$ and total phosphorous $(\mathrm{P})$, iron $(\mathrm{Fe})$ and calcium $(\mathrm{Ca})$ than fresh ones.

Two application rates of biosolids were defined considering (1) a value (50 ton ha ${ }^{-1}$, dry weight, d.w.) similar than the maximum rate allowed for soils having $\mathrm{pH}<6.5$ and metal (oids) according to the Chilean guidelines (Decree 4 of 2010, Ministerio Secretaría General de la Presidencia) and (2) two fold this rate (100 ton ha $^{-1}$, d.w.), as metal contaminated sites (primarily hard rock mining sites) in the United States have been restored with biosolids added at rates of 25 to 100 tons per hectare and higher (U.S. EPA, 2007).

\subsection{Experimental Assay}

Due to the acidic condition of polluted topsoil at Los Maitenes (Table 1), seashell grit (SG) from Sociedad
Contractual Minera Aceituno, a natural calcium carbonate-rich material (alkaline material), was used for primary acidity neutralization. Laboratory protocols for calculating the acid-base account from polluted study soils were used to determine the appropriate application rate to increase soil $\mathrm{pH}$ from 5.6 to 6.5 , as suggested by the U.S. EPA (2007) when excess As is also present in metal-polluted soils. Application rate of SG was $0.5 \%$ weight/weight (w/w), dry weight basis (d.w.).

To test the efficacy of fresh and air-dried biosolids for in situ immobilization of metals/As and improvement of physical, macronutritional, and microbiological properties of polluted topsoils, 7 experimental treatments, replicated 4 times, were defined as described in Table 3. The reference soil was used as a positive control $(\mathrm{C}+)$ while the polluted soil collected at Los Maitenes was used as a negative control (C-). Batches of polluted soil were amended with selected materials at the rates indicated in Table 3. Four kilograms of each experimental substrate were prepared in polyethylene containers; substrates were homogenized with an automatic roller for 20 minutes and distributed in four $1 \mathrm{~L}$ plastic pots with drainage at their base, filled up to $800 \mathrm{~mL}$. The remaining substrate of all treatments was used to determine the field capacity (FC), the wilting point (WP) and general physico-chemical characteristics, determined as described below.

Experimental pots were kept in a plant growth room under controlled conditions (temperature of $23 \pm 2^{\circ}$ $\mathrm{C}$; light intensity of $123 \pm 14.3 \mu \mathrm{mol} \mathrm{s} \mathrm{m}^{-1} ; 12: 12 \mathrm{~h}$ light:dark photoperiod) during fifteen weeks and randomly relocated once a week. During the first four weeks of experimentation, the soil moisture of every pot was checked once a week and deionized water was added when necessary (no leaching) to maintain each substrate at $70 \% \mathrm{FC}$. No further mixing of experimental substrates was performed at incubation period. At the beginning of the fifth week, all pots were sown with $0.6 \mathrm{~g}$ of seeds of Lolium perenne L. var. nui (perennial ryegrass), as this species has been frequently used to 
test metal (loid) toxicity in polluted soils (i.e. Arienzo et al., 2004). The soil moisture of every pot was daily checked and kept at $70 \% \mathrm{FC}$; irrigation was increased up to $90 \% \mathrm{FC}$ in those treatments with elevated plant yield by the end of the assay.

During the $14^{\text {th }}$ week of the assay, aliquots of soil pore water $(5-7 \mathrm{~mL})$ were taken from three experimental pots per treatment with Rhizon ${ }^{\circledR}$ Soil Pore Water Samplers (5-cm length; Rhizosphere Research Products, Wageningen, The Netherlands) following the methodology described by Vulkan et al. (2000). A composite sample per experimental treatment was produced in order to have enough volume for the chemical determinations. Soil pore water samples were kept in acid-washed polyethylene plastic vials $(15 \mathrm{~mL})$ and characterized as described below.

By week 15, aerial plant biomass was harvested per pot. Shoots were washed with deionized water to eliminate soil particles that were adsorbed on plant tissues, airdried at $45^{\circ} \mathrm{C}$ to a constant weight and weighed. Shoot $\mathrm{Cu}, \mathrm{Zn}$, and As contents were determined as described below. Pots were then longitudinally cut in halves for root cover determination A $1 \times 1 \mathrm{~cm}$ grid was over imposed on the exposed soil surface of one pot half and the number of intersection points effectively touched by roots from total intersection points was registered. Root cover (in percentage) was then calculated from the frequency of touches.

Table 3. Experimental treatments to evaluate the efficacy of both fresh and air-dried biosolids for in situ immobilization of metals/As and improvement of physical, macronutritional, and microbiological properties of polluted topsoils of the Puchuncaví Valley, central Chile. Polluted topsoils were neutralized with an alkaline material (seashell grit, SG) to a $\mathrm{pH}$ of 6.5 before incorporation of selected biosolids. C-, polluted soil at Los Maitenes; $\mathrm{C}+$, reference soil; $\mathrm{Bc}$, fresh biosolids (fresh); Bd, air-dried biosolids; 50, biosolids at 50 ton ha ${ }^{-1}(3 \%)$, d.w.*.; 100, biosolids at 100 ton ha-1 $(6 \%)$, d.w.*.

\begin{tabular}{lccc}
\hline Treatment code & $\begin{array}{c}\text { Seashell grit } \\
(\mathrm{SG}) \\
(\%)^{*}\end{array}$ & $\begin{array}{c}\text { Fresh biosolids } \\
(\mathrm{Bc}) \\
(\%)^{*}\end{array}$ & $\begin{array}{c}\text { Air-dried biosolids } \\
(\mathrm{Bd}) \\
(\%)^{*}\end{array}$ \\
\hline C+ & 0 & 0 & 0 \\
C- & 0 & 0 & 0 \\
SG & 0.5 & 0 & 0 \\
SGBc50 & 0.5 & 3 & 0 \\
SGBc100 & 0.5 & 6 & 0 \\
SGBd50 & 0.5 & 0 & 3 \\
SGBd100 & 0.5 & 0 & 6
\end{tabular}




\subsection{Analytical determinations of experimental substrates}

The FC of experimental substrates was determined according the method of Klute (1986) while the WP was determined according to Richards (1965). The $\mathrm{pH}$, electrical conductivity (EC), cation exchange capacity (CEC), total nitrogen, and available nitrogen $(\mathrm{N})$, phosphorous $(\mathrm{P})$ and potassium $(\mathrm{K})$ were determined after the procedures of USDA methods manual (USDA, 2004). The organic matter (OM) was analyzed by the Walkley Black method, as described in the USDA methods manual (USDA, 2004).

Samples of experimental substrates were subjected to microwave acid digestion (1200 Mega Microwave System, Milestone) and extraction (U.S. EPA method 3051 (U.S. EPA, 1995) and USDA method 3050 (USDA, 2004)) prior to trace metal determinations. Every digestion batch had one blank, one standard reference material sample, one duplicate sample, and one quality control sample. Digested samples were analyzed for total $\mathrm{Cu}, \mathrm{Zn}, \mathrm{Pb}, \mathrm{Cd}, \mathrm{Fe}, \mathrm{As}$, and $\mathrm{Ca}$ contents by flame atomic absorption spectrometry (FAAS, AAnalyst 300; Perkin-Elmer) under U.S EPA methods (U.S. EPA, 1995). Background non atomic absorption was corrected with a deuterium continuous lamp. The atomic absorption analytical device was housed in a class 1,000 clean-room laboratory, and the loading of the auto sampler tray was done in a class 100 laminar flow cabinet. The calibration standard was prepared with high-purity $(>$ $18 \mathrm{M} \Omega \mathrm{cm}^{-1}$ ) deionized water and acidified with $\mathrm{HNO}_{3}$ Suprapur (Merck) to $0.2 \%$. For performance control of the atomic absorption spectrometer, a certified multielement standard was used (Spectrascant Certified, Teknolab). The quality-assurance and quality-control criteria were satisfied when the measured characteristic of the standard reference material (Loam-B, catalog no. CRM-LO-B; HighPurity Standard; U.S.A.) and the quality-control sample (a previously characterized soil sample with a known concentration of metals) differed by no more than $5 \%$.

\subsection{Analytical determinations of pore water samples}

Determinations of free ionic copper $\left(\mathrm{Cu}^{2+}\right)$ were done in collected pore water samples up to $10 \mathrm{~min}$ after sample collection with a $\mathrm{Cu}$-ion selective electrode (Orion, model $9629 \mathrm{BN}$ ); the $\mathrm{Cu}$-ion specific electrode was calibrated using a diaminoacetic acid solution. From $\mathrm{Cu}^{2+}$ values the activity of the free $\mathrm{Cu}^{2+}$ ions or $\mathrm{pCu}^{2+}$ values were calculated according to $\mathrm{pCu}^{2+}=$ $-\log \left[\mathrm{Cu}^{2+}\right]$. Every pore water sample was then divided into two aliquots and fixed with either a $65 \%$ solution of $\mathrm{HNO}_{3}$ Suprapur (Merck) for elemental $(\mathrm{Cu}, \mathrm{Zn}, \mathrm{As}$, $\mathrm{Na}, \mathrm{Ca}$ and $\mathrm{Mg}$ ) determinations or with concentrated $\mathrm{H}_{3} \mathrm{PO}_{4}$ Suprapur (Merck) for dissolved organic carbon (DOC) determinations. The DOC was determined by combustion with the U.S. EPA method 415.1 (Keith, 1996) in a carbon analyzer (Tekmar Dohrmann Carbon Analyzer, model Apollo 9000). The calibration standard solution used was $1 \mathrm{mg} \mathrm{L}^{-1}$ as carbon of dipotassium phtalate for organic carbon. As reference material ION20 was used (National Waters Research Institute). Total $\mathrm{Cu}, \mathrm{Zn}$ and As were determined by FAAS (AAnalyst 300; Perkin-Elmer) under U.S. EPA methods (U.S. EPA, 1995), as described above.

\subsection{Analytical determinations of metals in plant tissues}

Dried ryegrass shoot samples were ground in an agate mortar and digested after the same protocol used for substrates. Every digestion batch included one blank sample, one standard reference material sample known as SRM 1573a tomato leaves or SRM 1570a spinach leaves (National Institute of Standards and Technology, U.S.A.), one duplicate sample and one quality control sample for the Quality Assurance and Control, QA/ $\mathrm{QC}$, criteria. The $\mathrm{Cu}, \mathrm{Zn}$, and As concentrations were determined by FAAS (Analyst 300, Perkin-Elmer) according to the U.S EPA methods (U.S. EPA, 1995).

\subsection{Microbial analysis}

Basal respiration was determined by placing $50 \mathrm{~g}$ of each experimental soil at $70 \%$ of $\mathrm{FC}$ and incubating the sample for 28 days in the dark at $28{ }^{\circ} \mathrm{C}$ in a $0.5 \mathrm{~L}$ 
closed vessel. Carbon dioxide $\left(\mathrm{CO}_{2)}\right.$ produced from experimental soils was trapped in a cup located inside the vessel having $10 \mathrm{~mL}$ of a $\mathrm{NaOH}$ solution $(1 \mathrm{~N})$. The $\mathrm{C}-\mathrm{CO}_{2}$ evolution was determined periodically by titration (Anderson, 1982). Basal respiration rate was calculated based on cumulative $\mathrm{CO}_{2}$ evolution over the 28 days period.

\subsection{Statistical analyses}

One way ANOVA $(\alpha=0.05)$ were used to contrast both microbiological (basal respiration) and plant variables (shoot biomass, root cover, and $\mathrm{Cu}, \mathrm{Zn}$, and As contents in shoots) under experimental treatments. The Fisher's Least Significant Difference (LSD) was used as a posteriori test. Simple Linear Regressions were used to evaluate statistical relationships among soil chemical variables. When needed, data were corrected for non-normality using logarithmic transformations $(\mathrm{x}=\log 10(\mathrm{x}+1))$ for the valid application of the parametric analyses described above. All statistical analyses were performed on Statistica software, version 6.0 (StatSoft Inc., U.S.A.).

Table 4. Wilting point (WP) and field capacity (FC) of experimental substrates at the beginning of the assay (week 1). Treatment codes follow Table 2.

\begin{tabular}{|c|c|c|}
\hline Treatment & $\begin{array}{c}\text { WP } \\
(\% \text { pp) }\end{array}$ & $\begin{array}{c}\text { FC } \\
\text { (g water }\end{array}$ \\
\hline $\mathrm{C}+$ & 5 & 24 \\
\hline C- & 5 & 25 \\
\hline SG & 5 & 26 \\
\hline $\mathrm{SGBc} 3$ & 6 & 30 \\
\hline SGBc6 & 7 & 39 \\
\hline SGBd3 & 31 & 24 \\
\hline SGBd6 & 34 & 27 \\
\hline
\end{tabular}

\section{Results and Discussion}

\subsection{Physicochemical characteristics of experimental substrates}

Physicochemical characteristics of experimental substrates at the beginning of the assay (week 1) are shown in Tables 4 to 6 . Incorporation of seashell grit (SG) into polluted soil (C-) allowed acidity neutralization to a $\mathrm{pH}$ value of 6.5 , as expected (Table 5). However, further addition of biosolids, either fresh or air-dried, resulted in higher $\mathrm{pH}$ values from neutral to slightly alkaline ( 7.0 to 7.3 ; Table 5 ), due to the alkaline characteristics of these materials (U.S. EPA, 2007; Kumpiene et al., 2008). Soil acidity neutralization with inorganic liming agents (i.e. $\mathrm{CaCO}_{3}, \mathrm{Ca}(\mathrm{OH})_{2}, \mathrm{CaO}$ ) is an effective traditional practice in acidic agricultural soils (Simon, 2005), but biosolids may also have soil neutralizing capabilities (Brown et al., 2003; U.S. EPA, 2007) which has to be also considered. Addition of biosolids into SG-amended soil increased organic matter $(\mathrm{OM})$ content of experimental substrates (Table 4) in a dose-dependent form, but no difference occurred among fresh and air-dried biolodis (Table 5) as they both have similar OM contents (Table 2). The water retention capability of soils at FC was increased after biosolids incorporation, particularly when fresh biosolids $(\mathrm{Bc})$ were added to soils and in a dose-dependent form (Table 5). However, incorporation of dried biosolids to polluted soils, irrespective of the application dose, resulted on excessive increases on the wilting point (WP) values (> $19 \%$ v.v.; Table 4). Soil moisture was clearly influenced by incorporation of biosolids to polluted soil but also by the type of biosolids (fresh or dried). While fresh biosolids increased both water retention capability of polluted soil and water availability to plants in soil, air-dried biosolids did not have such an effect on water retention capability of soil but excessively decreased the water availability to plants in soil (Table 5). Air-dried biosolids seems to need a long time to rehydrate when incorporated into soils and during this process they may compete for soil water with plant roots, particularly when high doses of air-dried biosolids are used and plants are seeded shortly after biosolids in corporation into soils. 
Table 5. General chemical parameters of experimental substrates at the beginning of the assay (week 1). Treatment codes follow Table 2 .

\begin{tabular}{|c|c|c|c|c|c|c|c|c|c|c|}
\hline Treatment & $\mathrm{pH}$ & $\begin{array}{c}\mathrm{EC} \\
\left(\mathrm{mScm}^{-1}\right)\end{array}$ & $\begin{array}{c}\text { CEC } \\
\text { (cnol. } \mathrm{kg}^{-1} \text { ) }\end{array}$ & $\begin{array}{l}\mathrm{OM} \\
(\%)\end{array}$ & $\begin{array}{c}\text { Total C } \\
(96) \\
\end{array}$ & $\begin{array}{c}\text { Total N } \\
(\%)\end{array}$ & $\mathrm{C} / \mathrm{N}$ & $\begin{array}{c}\mathrm{N}^{*} \\
\left.\text { (mg kg } g^{-1}\right)\end{array}$ & $\begin{array}{c}\mathrm{P}^{*} \\
\left.\text { (mg kg }{ }^{4}\right)\end{array}$ & $\begin{array}{c}\mathrm{K}^{*} \\
\text { (mg kg })\end{array}$ \\
\hline $\mathrm{C}_{+}$ & 6.30 & 0.17 & 8.55 & 1.25 & 0.73 & 0.06 & 12.08 & 15.3 & 33.1 & 267 \\
\hline C- & 5.58 & 0.14 & 9.07 & 2.10 & 1.22 & 0.09 & 13.50 & 29.4 & 42.5 & 216 \\
\hline SG & 6.47 & 0.16 & 8.04 & 1.93 & 1.12 & 0.08 & 13.99 & 31.1 & 41.1 & 218 \\
\hline SGBc3 & 7.32 & 1.04 & 9.33 & 2.97 & 1.72 & 0.21 & 8.19 & 427 & 96.0 & 216 \\
\hline SGBc6 & 7.01 & 1.48 & 10.6 & 4.28 & 2.48 & 0.24 & 10.34 & 457 & 152 & 233 \\
\hline SGBd3 & 7.09 & 1.23 & 8.30 & 2.67 & 1.55 & 0.15 & 10.31 & 280 & 90.5 & 229 \\
\hline SGBd6 & 7.32 & 1.77 & 9.33 & 3.81 & 2.21 & 0.14 & 15.79 & 515 & 105 & 273 \\
\hline
\end{tabular}

In the present study, the 4-week incubation time before seed sowing was insufficient to properly rehydrate airdried biosolids.

As expected, incorporation of biosolids resulted in higher contents of organic matter $(\mathrm{OM})$, total $\mathrm{N}$, available $\mathrm{N}$ and $\mathrm{P}$, and increased values of electrical conductivity (EC) in soil C-, generally in a dose-dependent form (Table 5). In general, no relevant differences among these characteristics were detected for fresh and airdried biosolids with the exception of EC (Table 5). Both fresh and air-dried biosolids have high EC values (Table 2), thus explaining their soil salinization effect when added to soil at high loading rates (i.e. Brown et al., 2003; Santibáñez et al., 2008). However, airdried biosolids resulted in higher EC values than fresh biosolids at the same rates of application, as the former have lower EC values $\left(14 \mathrm{mS} \mathrm{cm}\right.$ cm $^{-1}$ and $\mathrm{mS} \mathrm{cm}^{-1}$, respectively).

Total soil $\mathrm{Cu}, \mathrm{As}$, and $\mathrm{Cd}-\mathrm{Pb}$ were $3.3,2.5$, and 4.4 times higher in soil $\mathrm{C}$ - than in soil $\mathrm{C}+$, respectively, while $\mathrm{Zn}$ and $\mathrm{Fe}$ concentrations were alike (Table 6). Incorporation of amendments into soil C- did not change total $\mathrm{Cu}, \mathrm{Zn}, \mathrm{Fe}, \mathrm{Cd}, \mathrm{Pb}$, and $\mathrm{As}$ concentrations (i.e., there were no dilution effects by amendment mixing with soil) with the exception of $\mathrm{Ca}$, which increased (Table 6). Specifically, an increase from 1.4 to 2.2 times in total $\mathrm{Ca}$ concentrations was detected when seashell grit and biosolids were incorporated into soil C- (Table 6), as SG and biosolids are Ca-rich materials.

\subsection{Pore water chemistry of experimental substrates}

Chemical characteristics of soil pore water samples by week 14 are shown in Table 7 . The pore water $\mathrm{pCu}^{2+}$ value of soil $\mathrm{C}$ - was much lower than in $\mathrm{C}+$ (Table 7). The $\mathrm{pCu}^{2+}$ on $\mathrm{C}$ - was 2 units lower than in the $\mathrm{C}+$, thus meaning that activity of free $\mathrm{Cu}$ ions $\left(\mathrm{Cu}^{2+}\right)$ is much higher in $\mathrm{C}$ - soil than in $\mathrm{C}+$ soil. Incorporation of amendments increased $\mathrm{pCu}^{2+}$ values to values similar or even higher than the reference site $(\mathrm{C}+$; Table 7$)$, thus effectively and rapidly decreasing the concentration of free $\mathrm{Cu}^{2+}$ ions in soil pore water (short-term equilibration time). Addition of SG to soil C-reduced the activity of free copper ions in soil pore water to levels even lower than the reference soil $(\mathrm{C}+)$, an expected result as activity of free metal cations decreases as soil pH increases (Sauvé et al, 2000). Soil neutralization has been also commonly used to reduce metal (i.e. $\mathrm{Cu}, \mathrm{Zn}$, and $\mathrm{Ni}$ ) solubility in polluted soils (i.e. Simon, 2005; Bes \& Mench, 2008; Lee et al., 2011).The $\mathrm{pH}$ values play a crucial role in the mobility of metals in soils, as it govern directly the acid-base equilibria and affect both the solution and surface complexation reactions of metal cations, ion-exchange and other metal-binding processes 
Table 6. Total trace metal contents of experimental substrates at the beginning of the assay (week 1). Treatment codes follow Table 2.

\begin{tabular}{|c|c|c|c|c|c|c|c|}
\hline & \multicolumn{7}{|c|}{ Total metal $\left(\mathrm{mg} \mathrm{kg}^{-1}\right)$} \\
\hline & $\mathrm{Cu}$ & $\mathrm{Zn}$ & $\mathrm{Fe}$ & $\mathrm{Ca}$ & $\mathrm{Cd}$ & $\mathrm{Pb}$ & As \\
\hline $\mathrm{C}+$ & 209 & 115 & 48160 & 4392 & 0.21 & 19 & 20.7 \\
\hline C- & 685 & 159 & 49521 & 4391 & 0.90 & 84 & 51.1 \\
\hline SG & 619 & 147 & 47430 & 5624 & 0.63 & 67 & 50.9 \\
\hline SGBc3 & 711 & 197 & 47788 & 7460 & 0.84 & 73 & 51.3 \\
\hline SGBc6 & 649 & 196 & 47394 & 7629 & 0.68 & 63 & 53.4 \\
\hline SGBd3 & 593 & 163 & 43366 & 6003 & 0.93 & 74 & 44.8 \\
\hline SGBd6 & 691 & 234 & 51482 & 9672 & 0.91 & 74 & 56.4 \\
\hline
\end{tabular}

Table 7. General chemical parameters of soil pore water samples of experimental substrates by week 14 of the assay. Treatment codes follow Table 2 .

\begin{tabular}{lccccc}
\hline Treatment & $\begin{array}{c}\mathrm{DOC} \\
\left(\mathrm{mg} \mathrm{L}^{-1}\right)\end{array}$ & $\begin{array}{c}\text { Total Cu } \\
\left(\mathrm{mg} \mathrm{L}^{-1}\right)\end{array}$ & $\begin{array}{c}\text { Total Zn } \\
\left(\mathrm{mg} \mathrm{L}^{-1}\right)\end{array}$ & $\begin{array}{c}\text { Total As } \\
\left(\mathrm{mg} \mathrm{L}^{-1}\right)\end{array}$ & $\mathrm{pCu}^{2+}$ \\
\hline C+ & 88 & 0.36 & 0.78 & 12.1 & 8.2 \\
C- & 97 & 4.81 & 6.36 & 38.2 & 6.5 \\
SG & 95 & 0.81 & 0.10 & 39.6 & 9.6 \\
SGBc3 & 365 & 1.58 & 0.38 & 63.8 & 11.2 \\
SGBc6 & 490 & 1.82 & 0.89 & 73.5 & 11.1 \\
SGBd3 & 584 & 3.41 & 1.21 & 61.6 & 8.4 \\
SGBd6 & 890 & 5.44 & 2.54 & 62.4 & 10.3 \\
\hline
\end{tabular}

DOC, dissolved organic carbon

Addition of biosolids to SG-amended soils, further reduced free $\mathrm{Cu}^{2+}$ ion values, as these materials promote the sorption of metals and reduce metal solubilization into soil pore water, as shown by others (i.e. Brown et al., 2003; Kumpiene et al., 2008; Lee et al. 2011). For example, organic matter amendments, such as biosolids, composted yard waste, spent mushroom compost, peat, sludges, and cattle manure, can form stable organicmetal complexes at the solid phase when incorporated into metal-rich substrates, such as metal-polluted soils and hard rock mine wastes, as they have high cation exchange capacities (Sauvé et al., 2000; Simon, 2005). However, incorporation of air-dried biosolids resulted in lower $\mathrm{pCu}^{2+}$ values than air-dried ones (Table 7).
This may be explained by a larger presence of easily biodegradable organic compounds in air-dried biosolids, as reported by Fernández et al. (2007), which increased dissolved organic carbon (DOC) concentrations in pore water (Table 7).

A dose-dependent increase of dissolved organic carbon (DOC) resulted from incorporation of biosolids to the polluted study soil, which was higher after addition of air-dried biosolids (Table 7). This finding has been described in other biosolid-amended soils and hard-rock mine wastes (i.e. Santibáñez et al., 2008; Verdugo et al., 2011). In some cases, increased amount of DOC can increase metal mobility in the substrate (i.e. Santibáñez 
et al., 2008; Neaman et al., 2009), a phenomenon that was only relevant on SG soils amended with airdried biosolids, particularly at high doses (Table 7). Therefore, fresh biosolids were more effective for reducing both the concentration of total dissolved $\mathrm{Cu}$ and the activity of free $\mathrm{Cu}^{2+}$ ions in pore water than airdried ones (Table 7).

In the case of the metalloid As, total dissolved As showed increases from 1.6 to 1.9 times when biosolids were incorporated into SG-amended soils when compared to the soil C-, irrespective of the biosolid form (Table 7). Increased As solubilisation has been also demonstrated on amended $\mathrm{Cu}$ mine tailings (Verdugo et al., 2011) and on beringite amended Asenriched soils near an As-smelter in Belgium (Mench et al., 2006), particularly when substrate neutralization reached $\mathrm{pH}$ values higher than 6.5. Therefore, soil neutralization has to be carefully controlled to the target soil $\mathrm{pH}$ of 6.5 , as suggested by U.S. EPA (2007). In the present study, biosolids amended C- soils reached pHs higher than 7.0 (Table 5).

\subsection{Plant responses to experimental substrates}

Significant differences were found across experimental treatments for all assessed plant variables (Figures 1 and 2). The soil C- had adverse effects on the growth of ryegrass plants, reducing both the shoot biomass production (Figure 1) and the root cover (Figure 2) by $71 \%$ and $61 \%$, respectively, when compared to the productivity reached in the soil $\mathrm{C}+$. The same phytotoxicity results have been described for other plant species grown on soils artificially spiked with copper smelter dust (Sauvé et al., 2000; Ginocchio et al., 2006). In general, high metal-toxicity has been found in soils polluted with metal smelter dust, irrespective of the soil type (i.e. Ginocchio et al., 2006; Lee et al., 2011).

Addition of SG and biosolids to the soil C- resulted in significant increases in both shoot biomass production and root cover, reaching values even higher (1.1 to 2.5 times) than those for the soil $\mathrm{C}+$ (Figure 1). The same positive responses on ryegrass productivity have been demonstrated for other inorganic and/or organic amendments incorporated into highly polluted soils of the Puchuncaví Valley (i.e. Cárcamo et al., 2012). Exception was treatment SGBd6 where significantly lower shoot biomass resulted in comparison to treatment SGBd3 and where no significant difference in root cover was found with treatment C- (Figure 2).

When plant responses are compared among fresh and air-dried biosolids, it is interesting to note that in the case of fresh biosolids both shoot biomass and root cover do not vary with the dose incorporated to soil C-, while for air-dried biosolids a significant negative effects is related to the dose incorporated (Figures 1 and 2). Increased soil salinity and water stress to plants, resulting from the higher WP (Tables 4 and 5), could explain these adverse short-term effects in soils amended with airdried biosolids. According to Lu et al. (2012), higher concentrations of ammonium- $\mathrm{N}\left(\mathrm{NH}_{4}-\mathrm{N}\right)$ are displayed in thermally-dried biosolids when compared to fresh ones, particularly in the short time; even though we did not measure $\mathrm{NH}_{4}-\mathrm{N}$ in experimental treatments, this may be also an explanation for reduced plant productivity in soils amended with high doses of air-dried biosolids.

Polluted soil (C-) resulted in shoot $\mathrm{Cu}$ concentrations higher than $200 \mathrm{mg} \mathrm{kg}^{-1}$ (Table 8), a value well above the phytotoxic threshold described for the species (21-22 $\mathrm{mg} \mathrm{kg}^{-1}$; Adriano, 2001). This resulted in typical metaltoxicity visual symptoms, such as stunted growth with chlorotic and reddish leaves. However, shoot $\mathrm{Cu}$ and $\mathrm{Zn}$ concentrations of ryegrass plants grown in all the treatments where biosolids where incorporated did not differ from values of the soil $\mathrm{C}+$ and were below $43 \mathrm{mg}$ $\mathrm{kg}^{-1}$ and $197 \mathrm{mg} \mathrm{kg}^{-1}$, respectively (Table 8), and are in the range considered normal for plants (Adriano, 2001). In general, addition of biosolids significantly reduced As concentrations in shoots when compared to concentration in shoots of plants grown on soil C-, but they were significantly higher than levels found in plants grown on soil $\mathrm{C}+($ Table 8$)$. However, they were within the normal range of As described for plants (Adriano, 2001). 
Table 8. Trace metal content in shoots of ryegrass plants by the end of the assay (week 15). Mean and standard deviation are shown $(\mathrm{N}=3)$. Treatment codes follow Table 2. Different letters inside each trace metal indicate significant differences among experimental treatments.

\begin{tabular}{lccc}
\hline Treatment & \multicolumn{3}{c}{ Metal(loid) in shoot $\left(\mathrm{mg} \mathrm{kg}^{-1}\right)$} \\
& $\mathrm{Cu}$ & $\mathrm{Zn}$ & $\mathrm{As}$ \\
\hline $\mathrm{C}+$ & $25 \pm 1.8 \mathrm{a}$ & $189 \pm 3.1 \mathrm{bc}$ & $0.9 \pm 0.03 \mathrm{a}$ \\
$\mathrm{C}-$ & $218 \pm 50.3 \mathrm{~b}$ & $442 \pm 53.6 \mathrm{~d}$ & $6.9 \pm 1.02 \mathrm{~d}$ \\
SG & $40 \pm 0.7 \mathrm{a}$ & $164 \pm 27.8 \mathrm{abc}$ & $4.6 \pm 0.32 \mathrm{c}$ \\
SGBc3 & $42 \pm 6.5 \mathrm{a}$ & $136 \pm 1.4 \mathrm{a}$ & $2.5 \pm 0.49 \mathrm{~b}$ \\
SGBc6 & $43 \pm 16.5 \mathrm{a}$ & $150+13.8 \mathrm{ab}$ & $1.9 \pm 0.77 \mathrm{ab}$ \\
SGBd3 & $42 \pm 3.1 \mathrm{a}$ & $197 \pm 7.5 \mathrm{c}$ & $3.0 \pm 0.79 \mathrm{~b}$ \\
SGBd6 & $39 \pm 7.2 \mathrm{a}$ & $154 \pm 18.5 \mathrm{abc}$ & $2.1 \pm 0.39 \mathrm{~b}$ \\
\hline
\end{tabular}

One-way ANOVA, LSD Fisher

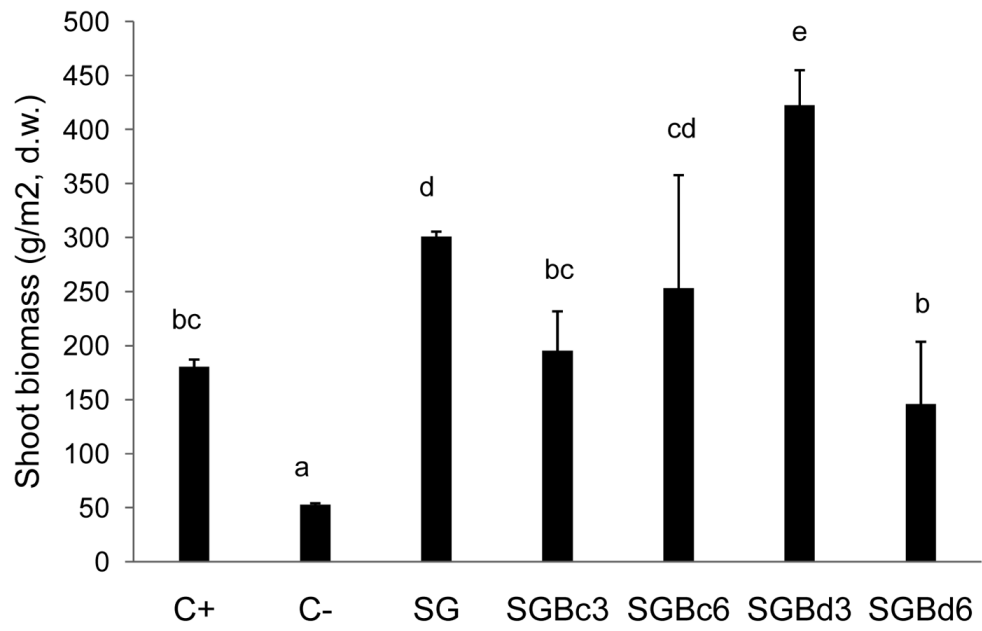

Figure 1. Shoot biomass (dry weight basis) of ryegrass plants grown during 15 weeks on experimental substrates. Mean and standard deviation are shown $(\mathrm{N}=3)$. Treatment codes follow Table 2. Different letters inside each trace metal indicate significant differences among experimental treatments. 


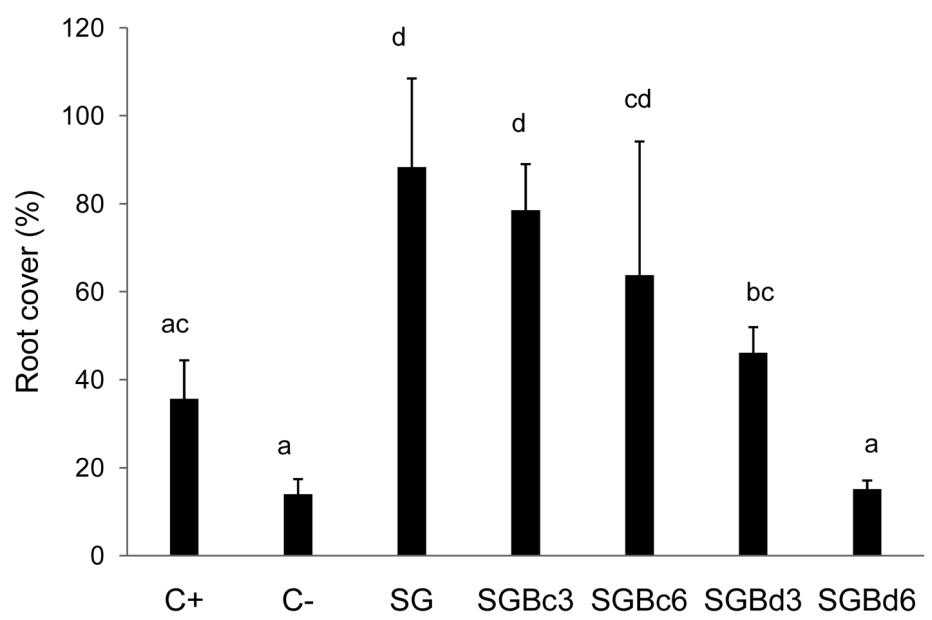

Figure 2. Root cover of ryegrass plants grown during 15 weeks on experimental substrates. Mean and standard deviation are shown $(\mathrm{N}=3)$. Treatment codes follow Table 2. Different letters inside each trace metal indicate significant differences among experimental treatments.

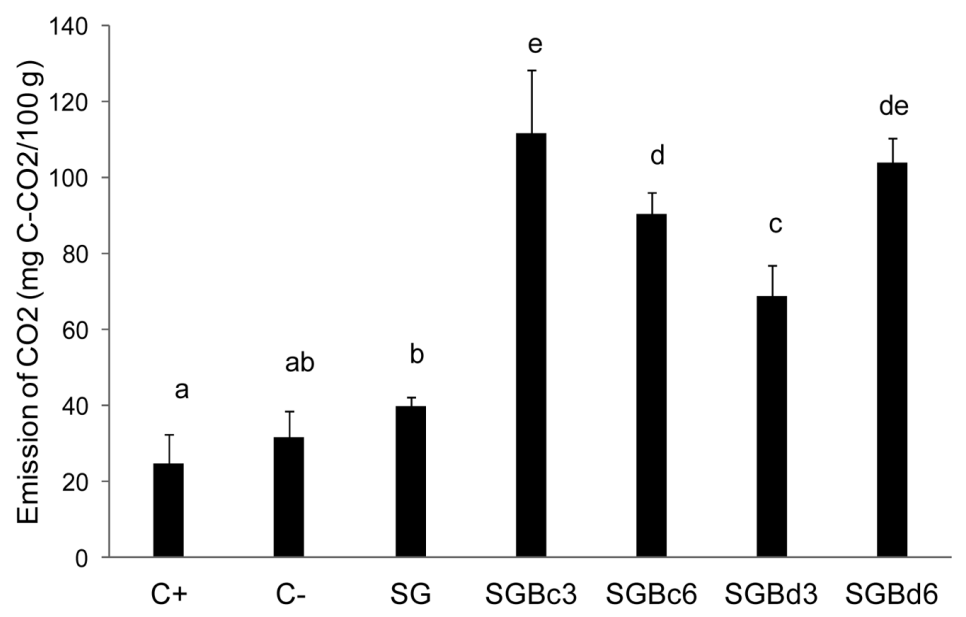

Figure 3. Microbial activity on experimental substrates. Mean and standard deviation are shown $(\mathrm{N}=3)$. Treatment codes follow Table 2. Different letters inside each trace metal indicate significant differences among experimental treatments. 


\subsection{Microbial Activity}

No significant differences were found for soil microbial activity among soils $\mathrm{C}$ - and $\mathrm{C}+$ (Figure 3 ), indicating that microbial activity was not affected by historical pollution. Addition of SG to soils C- did not resulted in any significant impact on soil microbial activity but it was significantly increased by incorporation of biosolids, either fresh or air-dried (Figure 3). However, no clear trends were found among biosolids type and dose incorporated into soils C-. It is well known that incorporation of organic amendments to trace metal degraded soils or in hard rock mine wastes, such as biosolids, may improve or re-establish microbial populations and thus increase microbial activity (i.e Haering et al., 2000; Brown et al., 2003.).

\section{Conclusions}

Fresh and air-dried biosolids are effective organic amendments for remediation of acidic and metal/ As-rich soils of the Puchuncaví valley, as they both improve soil $\mathrm{OM}$, fertility (total $\mathrm{N}$ and available $\mathrm{N}$ and $\mathrm{P}$ ), and microbial activity, in a dose-dependent form. However, fresh biosolids would be a better alternative for soil remediation in the study area as they better improve water retention capability and water availability in soils to plants and reduced soil metal/As solubilization when compared to air-dried ones. In terms of plant productivity, fresh biosolids and low doses of air-dried biosolids are effective soil amendments for polluted soils of the Puchuncaví valley. However, incorporation of high doses of airdried biosolids may limit plant productivity, probably due to soil salinity and water stress, particularly when short incubation time is given in soils.

\section{Acknowledgements}

The present study was funded by the FONDECYT grant project 1085005 . Authors would like to thank Paola Arata of Aguas Andinas S.A. and Eduardo
Barbieri of Sociedad Contractual Minera Aceituno for providing the amendments used in the present study.

\section{References}

Adriano, D.C. 2001. Trace elements in terrestrial environments. Biogeochemistry, bioavailability, and risk of metals. Springer-Verlag,New York, NY.

Anderson, J.P.E. 1982. Soil respiration. In: Page, A.L. (ed). Methods of Soil Analysis, Part 2. Chemical and Microbiological Properties. Soil Science Society of America, Madison, Wisconsin, pp: $837-$ 871.

Arienzo, M., Adamo, P., Cozzolino V. 2004. The potential of Lolium perenne for revegetation of contaminated soil from a metallurgical site. Science of the Total Environment. 319, 13-25.

Bes, C., Mench, M. 2008. Remediation of coppercontaminated topsoils from a wood treatment facility using in situ stabilisation. Environmental Pollution. 156, 1128-1138.

Brown, S., Henry, C.L., Chaney, R., Compton, H., De Volder, P. 2003. Using municipal biosolids in combination with other residuals to restore metalcontaminated mining areas. Plant and Soil. 249, 203-215.

Brown, A., Svendsen, A., Henry, C. 2009. Restoration of higher $\mathrm{Zn}$ and $\mathrm{Pb}$ tailings with municipal biosolids and lime. A field study. Journal of Environmental Quality. 38, 2184-2197.

Cárcamo, V., Bustamante, E., Trangolao, E., de la Fuente, L.M., Mench, M., Neaman, A., Ginocchio, R. 2012. Simultaneous immobilization of metals and arsenic in acidic polluted soils near a copper smelter in central Chile. Environ. Sci.Pollut. Res. 19, 1131-1143. 
Environmental Resources Management. 1993. Environmental project. Ventanas region, Chile. Vol. 1: Final report. London: Environmental Resources Limited, UK.

Fernández, J.M., Plaza, C., Hernández, D., Polo, A. 2007. Carbon mineralization in an arid soil amended with thermally-dried and composted sewage sludges. Geoderma. 137, 497-503.

Ginocchio, R. 2000. Effects of a copper smelter on a grassland community in the Puchuncavi valley, Chile. Chemosphere. 41,15-23.

Ginocchio, R., Sánchez, P., de la Fuente, L.M., Camus, I., Bustamante, E., Silva, Y., Urrestarazu, P., Torres, J.C., Rodríguez, P.H. 2006. Agricultural soils spiked with copper mine wastes and copper concentrate: Implications for copper bioavailability and bioaccumulation. Environmental Toxicology and Chemistry. 25, 712-718.

González, I., Muena, V., Cisternas, M., Neaman, A. 2008. Acumulación de cobre en una comunidad vegetal afectada por contaminación minera en el valle de Puchuncaví, Chile central. Revista Chilena de Historia Natural. 81, 279-291.

Haering, K.C., Daniels, W.L., Feagley, S.E. 2000. Reclaiming mined land with biosolids, manures and papermill sludge. In: R.I. Barnhisel, Darmody, R.G. (eds). Reclamation of drastically disturbed lands. Agronomy Monograph n. 41. American Society of Agronomy, Madison, 615-644.

Keith, L.H. 1996. Compilation of EPA's sampling and analysis methods, 2nd edition. Lewis, Boca Raton.

Klute, A. 1986. Methods of soil analysis. Physical and mineralogical methods. V1. American Society of Agronomy, Madison, Winsconsin, 1159p.

Kumpiene, J., Lagerkvist, A., Maurice, C. 2008. Stabilization of $\mathrm{As}, \mathrm{Cr}, \mathrm{Cu}, \mathrm{Pb}$ and $\mathrm{Zn}$ in soils using amendments. A review. Waste Manag. 28, 215-225.
Lee, S.H., Kim, E.Y., Park, H., Yun J, Kim, J.G 2011. In situ stabilization of arsenic and metalcontaminated agricultural soil using industrial byproducts. Geoderma. 161, 1-7.

Lu, Q., He, Z.L., Stoffella, P.J. 2012. Land application of biosolids in the USA: A review. Applied and Environmental Soil Science. Doi: 10.1155/2012/201462.

Mench, M., Vangronsveld, J., Beckx, C., Ruttens A. 2006. Progress in assisted natural remediation of an arsenic contaminated polluted soil. Environmental Pollution. 144, 51-61.

Neaman A, Reyes L, Trolard F, Bourrié G, Sauvé S. 2009. Copper mobility in contaminated soils of the Puchuncaví valley, central Chile. Geoderma. 150, 359-366.

Richards, L.A. 1965. Physical conditions of water in soil. In: C.A. Black (ed). Methods of soil analysis. Part 1. Physical and mineralogical properties, including statistics of measurement and sampling. American Society of Agronomy, Madison, WI, USA, pp: 128-152.

Santibáñez, C., Verdugo, C., Ginocchio, R. 2008. Phytostabilization of copper mine tailings with biosolids: implications for metal uptake and productivity of Lolium perenne. Science of the Total Environment. 395, 1-10.

Sauvé, S., Hendershot, W., Allen, H. 2000. Solidsolution partitioning of metals in contaminated soils: dependence on $\mathrm{pH}$ and total metal burden. Environ. Sci. Technol. 34, 1125-1131.

Simon, L. 2005. Stabilization of metals in acidic mine spoil with amendments and red fescue (Festucarubra L.) growth. Environmental Geochemistry and Health. 27, 289-300.

USDA. 2004. Soil Survey Laboratory Methods Manual. Soil Survey Investigations Report $N^{\circ} 42$, 
version 4.0, National Soil Survey Center, Natural Resources Conservation Service, United States Department of Agriculture, Lincoln.

U.S. EPA. 1995. Test methods for evaluating solid waste: physical/chemical methods. 3rd edition. EPA 530/ SW-846. Office of Solid Waste, The Environmental Protection Agency, Springfield.

U.S. EPA. 2007. The use of soil amendments for remediation, revitalization, and reusue. EPA 542R-07-013. Office of Superfund Remediation and Technology Innovation (OSRTI). EPA/National Service Center for Environmental Publications, Cincinnati.
Verdugo, C., Sánchez, P., Santibáñez, C., Urrestarazu, P., Bustamante, E., Silva, Y, Gourdon, D., Ginocchio, R. 2011. Efficacy of lime, biosolids and mycorrhiza for the phytostabilization of sulfidic copper tailings in Chile: a greenhouse experiment. Int. J. Phytoremedia. 13, 107-125.

Vulkan, R., Zhao, F-J., Barbosa-Jefferson, V., Preston, S., Paton, G.I., Tipping, E., McGrath, S. 2000. Copper speciation and impacts on bacterial biosensors in the pore water of coppercontaminated soils. Environ. Sci.Technol. 34, 5115-5121.

Wang, H., Brown, S.L., Magesan, G.N. 2008. Technological options for the management of biosolids. Environ Sci. Pollut Res. 15, 308-317. 